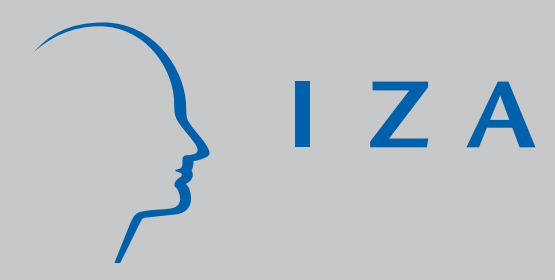

IZADP No. 2392

The Economics of Citizenship: A Common Intellectual Ground for Social Scientists?

Don J . DeVoretz

October 2006 


\title{
The Economics of Citizenship: A Common Intellectual Ground for Social Scientists?
}

\author{
Don J. DeVoretz \\ RIIM, Simon Fraser University \\ and IZA Bonn
}
Discussion Paper No. 2392
October 2006

\author{
IZA \\ P.O. Box 7240 \\ 53072 Bonn \\ Germany \\ Phone: +49-228-3894-0 \\ Fax: +49-228-3894-180 \\ Email: iza@iza.org
}

\begin{abstract}
Any opinions expressed here are those of the author(s) and not those of the institute. Research disseminated by IZA may include views on policy, but the institute itself takes no institutional policy positions.

The Institute for the Study of Labor (IZA) in Bonn is a local and virtual international research center and a place of communication between science, politics and business. IZA is an independent nonprofit company supported by Deutsche Post World Net. The center is associated with the University of Bonn and offers a stimulating research environment through its research networks, research support, and visitors and doctoral programs. IZA engages in (i) original and internationally competitive research in all fields of labor economics, (ii) development of policy concepts, and (iii) dissemination of research results and concepts to the interested public.
\end{abstract}

IZA Discussion Papers often represent preliminary work and are circulated to encourage discussion. Citation of such a paper should account for its provisional character. A revised version may be available directly from the author. 
IZA Discussion Paper No. 2392

October 2006

\section{ABSTRACT}

\section{The Economics of Citizenship: A Common Intellectual Ground for Social Scientists?}

Economists studying the economic behaviour of immigrants have tended to avoid serious interdisciplinary work. I argue that when presented with a particular set of research questions that lend themselves to a utility maximisation framework, an economist will be able to pursue interdisciplinary work. I further argue that the necessary if not sufficient ingredient for true economic collaborative research has been met in the field of citizenship acquisition. I review the existing empirical research on citizenship acquisition and its economic impacts to support this argument.

JEL Classification: J61, J68, F22

Keywords: immigration, citizenship, methodology

Corresponding author:

Don J. DeVoretz

RIIM

Simon Fraser University

Burnaby, BC V5A 156

Canada

E-mail: devoretz@sfu.ca 


\section{Introduction}

Since 1996, the Metropolis Project in Canada has attempted to draw together multidisciplinary networks in Vancouver, Halifax, Toronto, Montreal and the Canadian Prairies to study the impact of recent immigrant arrivals on these cities. ${ }^{1}$ The central intellectual thrust of this largely successful project is that the process of immigrant integration can only be understood if economists, geographers, sociologists and other social scientists explore a common research agenda.

It is interesting to note that both financial and institutional structures were put into place to encourage multidisciplinary research projects at the Vancouver Centre. In particular, the Centre awards research grants on the basis of their degree of interdisciplinary content. One clear lesson has emerged: economists have been largely unable to do serious collaborative work with other social scientists while studying immigration. The most telling example that clearly portrays the existence of these two solitudes, economists and other social scientists, arose in the first three years of the monthly putative multidisciplinary seminars at the Vancouver Centre. In short, when economists gave a paper, only economists were in the audience, but when other social scientists gave a paper, there appeared a blending of social scientists including an occasional economist. Thus, the experiment of a multidisciplinary immigration seminar was, de facto, declared a failure by the economics group after three years. Now there exists a monthly economics seminar on immigration with a periodic more multidisciplinary seminar at a separate location.

What caused the failure of this earnest attempt? After all, major immigration journals publish work across a variety of fields to explain the integration process of immigrants. ${ }^{2}$ Moreover, why are economists so uniquely unable to collaborate with other social scientists in this field? One is tempted to use hubris as the primary explanatory tool, but more substantive arguments may lie in the restrictive formal modelling structure that is inherent in the economics paradigm. Moreover, the advent of applied econometrics as a major investigative tool in the economics of immigration has tended to isolate the economist's audience and also tempted economists to marginalise empirical work on immigration that does not involve substantial data sets. ${ }^{3}$

The central thesis of this essay is that to expand an economist's horizon across two or more disciplines while researching the integration of immigrants requires positing a uniquely 
defined research question. More precisely, the research question must lend itself to the economic paradigm of utility maximisation, which in turn allows the derivation of hypotheses. These hypotheses in turn must be subjected to tests with available large data sets to refute or support the hypotheses in question to satisfy the economist's curiosity.

However, the existence of a potentially cogent question embedded in a utility maximisation framework is not sufficient to create true multidisciplinary work by an economist. The economist's model must also incorporate central features of the relevant political, social or geographical environment in his/her economic model to go beyond simple economic imperialism. There are several emerging topics or questions that readily lend themselves to economists meaningfully branching out, but this paper will focus on the emerging research in the economics of immigrant citizenship acquisition. ${ }^{4}$

Seminal work on this topic began under the aegis of the Willi Brandt Professorship at Malmö University in 2004 when an exploratory workshop brought together European and North American economists, sociologists, political scientists and an anthropologist. The aim of this workshop was to draw up a common set of research questions and an acceptable methodology to explore the motivation for immigrant citizenship acquisition. After ten paper presentations, the consensus of this group was that there did not exist a common methodology shared across all disciplines, especially economics. However, two broad questions emerged which piqued the interests of all participants. Namely, why do immigrants ascend to citizenship at differential rates, and what are the political, social and economic consequences of this ascension?

Thus, I argue that the necessary, if not sufficient, ingredient for true economic collaborative research has been met in the field of citizenship acquisition by defining a set of questions with broad interests across social science. I will also argue that addressing this question will allow an analysis under a utility maximisation framework. The remaining portions of this paper will first present a limited literature review to emphasise the two separate branches of research by economists and other social scientists on this topic. Next, I will present some Canadian evidence on substantial economic gains inherent in citizenship acquisition which will help substantiate the thesis that economic gains will feedback on citizenship acquisition. I will also note that there exists a wide array of costs and benefits that will ultimately condition the decision to become a citizen. In the final section I will estimate 
the sources of the economic gain owing to citizenship by measuring the contribution of immigrants' human capital acquisition prior to citizenship and society's valuation of this acquired human capital. In addition, I will measure the degree of positive discrimination which may favour naturalised Canadian citizens and lead to their higher incomes. Finally, I conclude with some observations about expanding this new common ground for social scientists in immigrant citizenship acquisition research.

\section{Literature Review of Citizenship Acquisition and Impact}

The purpose of this literature review is not to provide an exhaustive list of publications, but rather, to demonstrate the fragmented nature of immigrant naturalisation research to date.

Prior to the work of DeVoretz and Pivnenko (2005) the extant economic literature concentrated on only one aspect of the immigrant citizenship question, namely the economic impact of naturalisation. The economic analysis by Bratsberg et al. (2002) illustrates this point when they choose only to investigate the earnings and employment prospects of citizens and non-citizens in the United States labour market. They found that selected groups of United States immigrants received an economic reward from immigrant ascension. ${ }^{5}$ This labour market impact approach in the economics literature has been replicated by many authors in a variety of contexts. Both Scott (1999) and Bevelander (2000) argue that the impact of citizenship acquisition in the Swedish context was negative as labour market participation is diminished after naturalisation. Pivnenko and DeVoretz (2004) argued that Ukrainian immigrants resident in either the United States or Canada earned an income premium after citizenship acquisition in either country. The conclusion to be drawn from this selective review is that the economics profession only addressed one-half of the questions appearing in the immigrant-citizenship research nexus and neglected to ask why immigrants naturalise at differential rates.

There of course exists a second and separate branch of literature on the naturalisation process which has been until very recently addressed only by sociologists and political scientists. This literature addresses the prior question of why immigrants ascend to citizenship at differential rates. The primary example of this literature is owing to Yang (1994) who focused on the conditioners of immigrant ascension to citizenship by providing a lifecycle model which contained demographic, social and political variables. Yang's 
sociological model, whilst identifying the importance of dual citizenship, home ownership, age and gender to explain United States immigrant citizenship acquisition was defined on an ad hoc basis. ${ }^{6}$ Mata (1999) repeated this methodological ad hoc approach (i.e. no model) when he confronted the question of Canadian immigrant naturalisation with a vector analysis to isolate the relative contribution of economic and non-economic forces in determining take up rates of citizenship. Mata concluded that there exists no economic argument to support immigrant naturalisation and that non-economic forces are more significant. Bloemraad (2000) again addressed the question of Canadian immigrant naturalisation and highlighted the importance of the dual citizenship option that is open to some immigrants, which significantly affected naturalisation rates. Thus, the conclusion to be drawn from this separate body of literature is that the ascension decision, when researched in isolation from the impact decision, leaves a minor role for economic determinants or begs for a more rigorous model construction with a cross-disciplinary component. As I will demonstrate below, when I merge the ascension and impact analysis a common ground of analysis for social scientists will appear.

These two separate streams of literature cited above when researched in isolation both ignore the general equilibrium nature of immigrant decisions. In other words, utilitymaximising decisions made by an immigrant in the ascension process will have an impact in the immigrant's labour market. Economists typically assume that the individual acquires information about these effects by looking to a representative individual in her community. For example, immigrants may accumulate greater human capital prior to citizenship to enjoy the benefits obtained from citizenship. Moreover, the impact in the second market may induce a feedback effect in the first market. This is the key insight that allows a resourceful economist to merge the immigrant ascension question to the economic impact question and to create a common ground for which economic, geographic, political and sociological arguments can be merged to examine the immigrant-citizenship question. ${ }^{7}$

There is an even more profound insight common, but not exclusive, to the economic paradigm that necessitates the merging of the ascension and impact effects of immigrant naturalisation, thus potentially providing a common research agenda for economists and other social scientists. In short, the decision to ascend and the economic impact may be endogenous (DeVoretz and Pivenko 2005). To wit, the choice of ascending to citizenship 
may not be independent of the economic impact of citizenship acquisition in the labour market and vice-versa. In other words, if you expect to earn a premium from citizenship you may invest in yourself in anticipation of citizenship by acquiring more education and linguistic skills and further integrate socially and politically into your community which will simultaneously affect your decision to become a citizen.

In sum, economic methodology strongly supports the merging of the ascension and impact dimensions of citizenship acquisition. Once this merger of the two questions is recognised then the economist has a common ground to work with other disciplines on both questions that heretofore were addressed in isolation.

\section{Immigration, Citizenship and Earnings: Some Stylised Facts}

In order to make my case that there are significant economic gains to be earned from citizenship I present some stylised facts below. Barry Chiswick (1978) in his seminal work on immigrant earnings posited the concept of the catch-up in the race to close the earnings gap between immigrants and native-born in the United States but denied the existence of a citizenship effect. Central to this concept of the catch-up is that immigrants enter the economy at a disadvantage since they lack specific human capital as well as language skills and knowledge of the labour market (general human capital) upon entry. This gap will dissipate with time and greater human capital acquisition. After 10-15 years, the foreign born and Canadian born should have equal earnings. Thereafter, the double self-selection inherent in the immigration process would assure that within each skill cohort the representative foreign-born worker would outperform a native-born worker. Double selection occurs since the immigrant self-selects to move in the first stage and in the second stage the receiving country selects or rejects this immigrant arrival. Canada’s explicit point system evaluates the principal applicant and hence double selection is ensured in this context.

Figure 1 depicts the optimistic and pessimistic views of the earnings 'catch-up' model. Immigrants upon entry earn considerably less until $\mathrm{X}$ as they must accumulate specific human capital to 'catch-up' to their native-born cohort's earnings. In the optimistic case with no labour market impediments and considerable human capital investment immigrants catch up and then outperform their earnings cohort given their superior unobservable endowments (e.g. intelligence, energy) owing to their double selection. In the pessimistic case immigrants 
either are unable or choose not to accumulate human capital and never achieve a catch-up point.

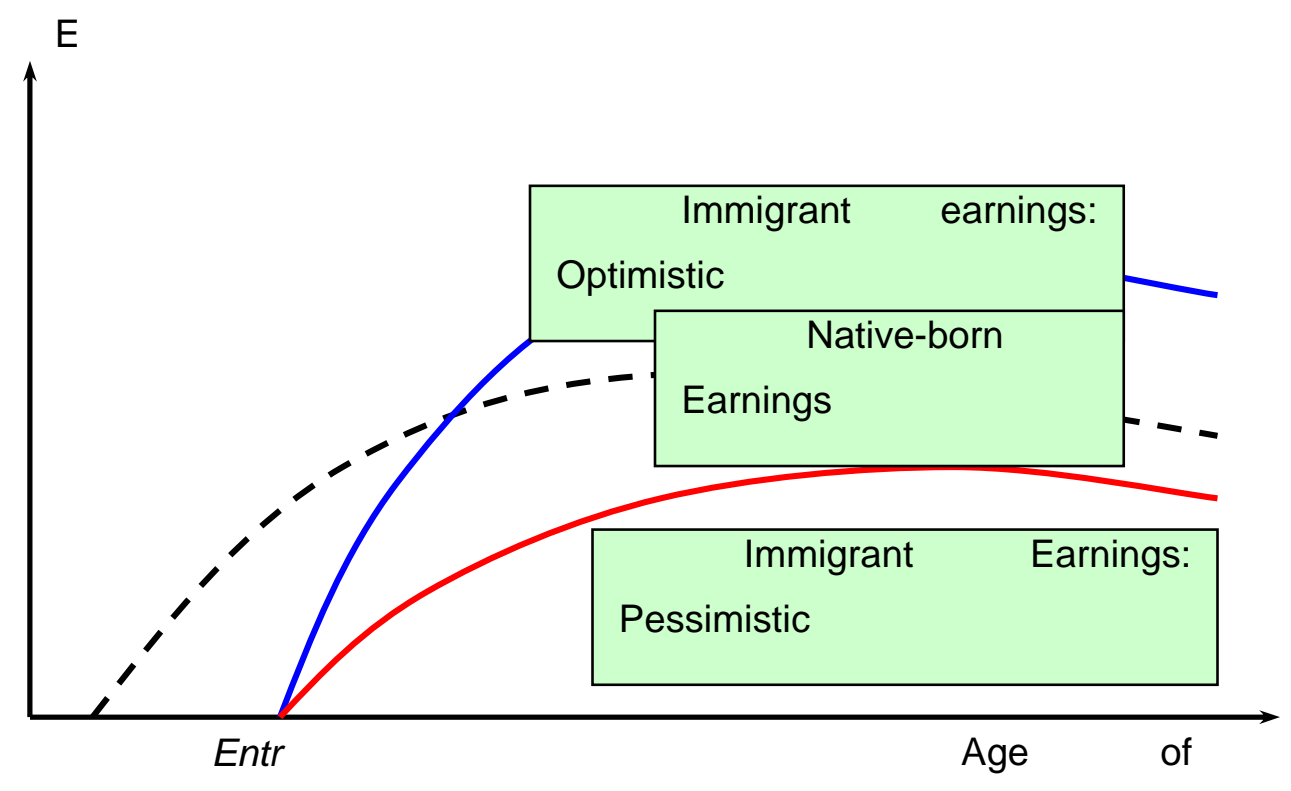

However, Chiswick argues that naturalisation does not affect this earnings catch-up since any observed citizenship effect is simply owing to years of residence whilst awaiting citizenship eligibility. An empirical rebuttal to this argument is presented below with selected Canadian evidence.

DeVoretz and Pivnenko (2006) documented in the Canadian case that the act of acquiring citizenship resulted in an upward shift in the naturalised immigrant's earnings. Figures 2 and 3 illustrate the citizenship effect on earnings for pairs of old (British and United States) and new (Chinese and Indian) vintages of Canadian immigrants. ${ }^{8}$ Figure 2 indicates sizeable citizenship effects for both the Chinese and the British. However, the citizenship effect on Chinese earnings is larger. The Canadian-born age earnings functions are reported as a reference point (CB), and further highlight the citizenship effect on earnings. As noted a 
Chinese immigrant experiences a substantial earnings disadvantage upon arrival, but by becoming a citizen his/her earnings rise such as to nearly equal that of the Canadian-born. The observed citizenship effect on British immigrant earnings is smaller but sufficient to make these immigrants 'overachievers'. In other words, without citizenship British immigrants do not suffer an initial earnings disadvantage relative to the Canadian-born. However after obtaining citizenship British immigrants become overachievers and earn more than the Canadian-born.

Figure 2 Age-earnings profiles for the Canadian Born (CB), British Immigrants Canadian citizens (Britlm_C) and non-citizens of Canada (BritIm_NC), Chinese Immigrants Canadian citizens (ChinIm_C) and non-citizens of Canada (Chinlm_NC)

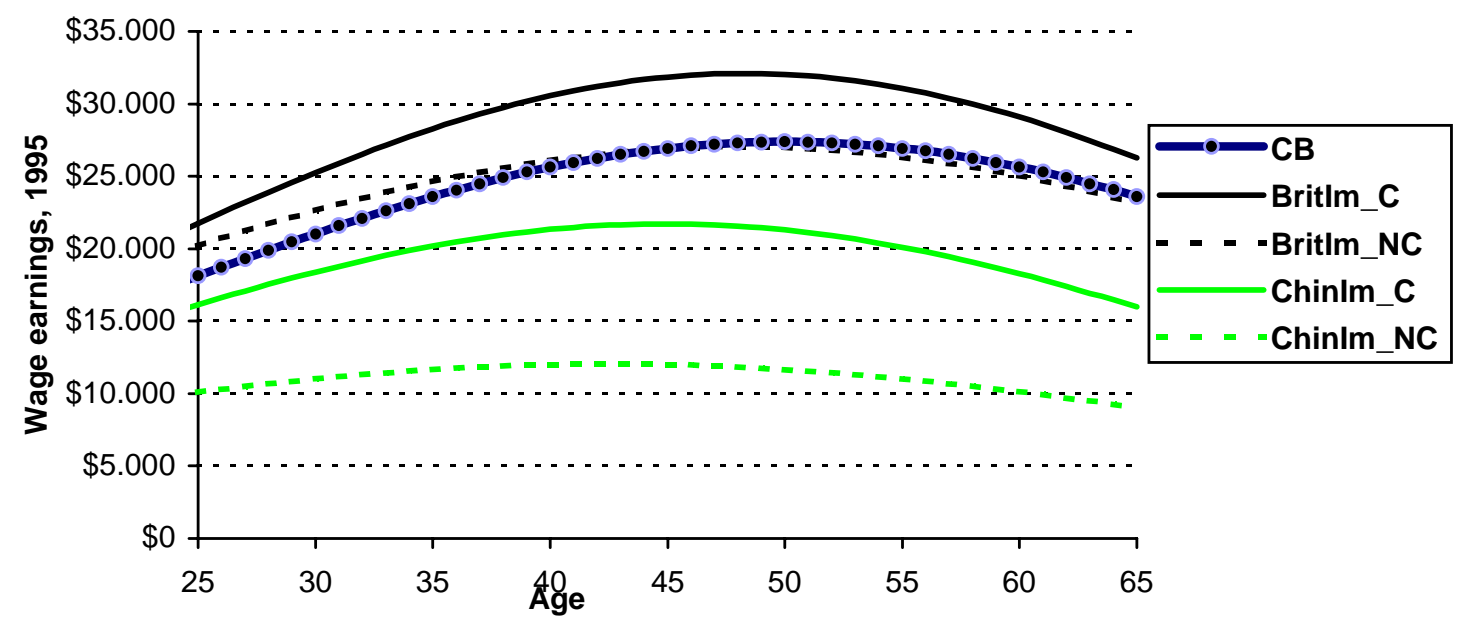

Source: Authors' calculations from 1991, 1996 and 2001 Census of Canada

Figure 3 portrays a similar effect when we pair the earnings performance for the United States and Indian immigrants. Citizenship status grants United States immigrants a slight lifetime earnings premium relative to the Canadian-born. There is once again a substantial boost in the earnings of Indian immigrants from citizenship acquisition, such that Indians nearly replicate the earnings of the Canadian-born. 
Figure 3 Age-earnings profiles for the Canadian Born (CB), US Immigrants Canadian citizens (USIm_C) and non-citizens of Canada (USIm_NC), Indian Immigrants Canadian citizens (IndIm_C) and non-citizens of C- anada (IndIm_NC)

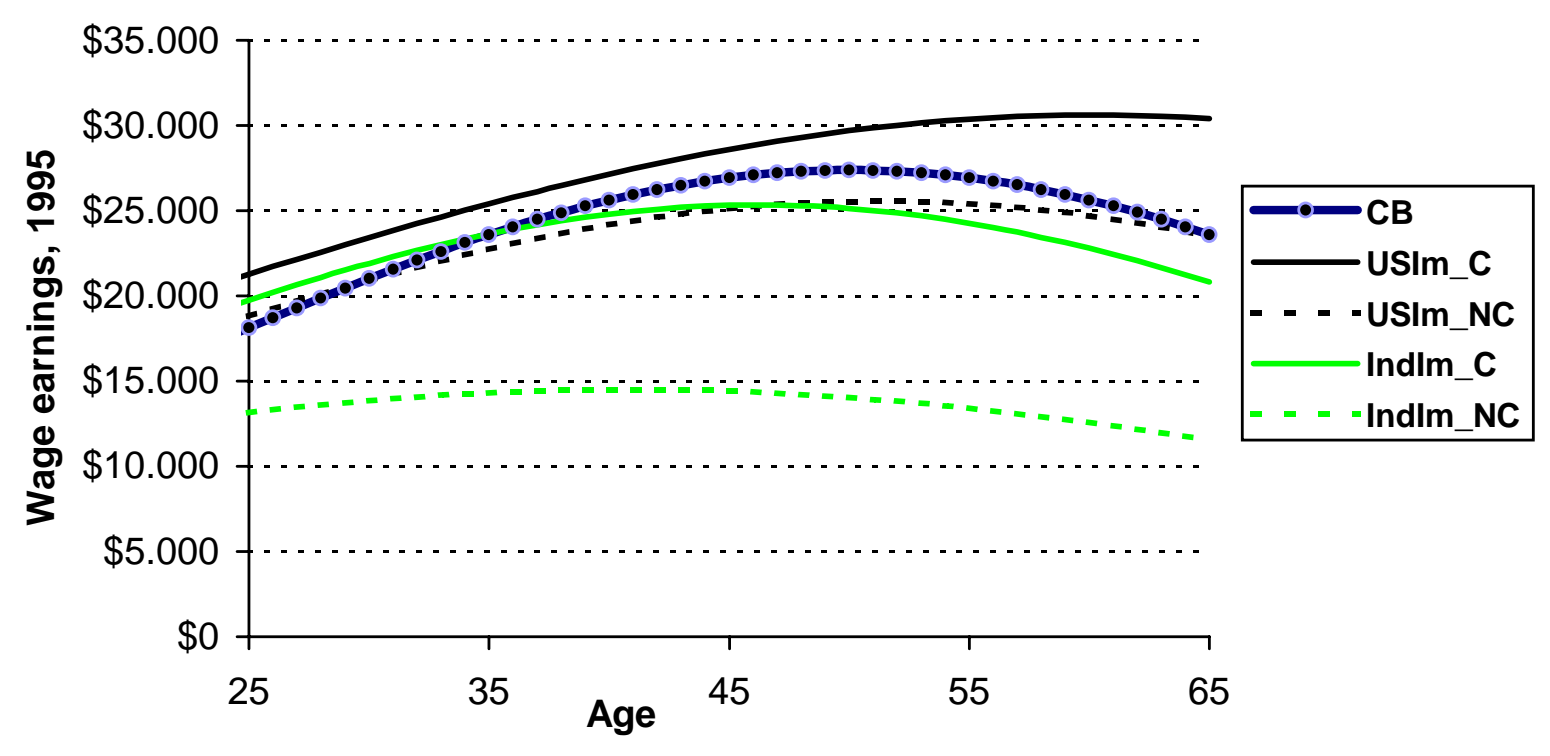

Source: Authors' calculations from 1991, 1996 and 2001 Census of Canada

Figure 4 reports the citizenship acquisition effect in terms of Canadian employment rates in 2001. In the employment context the citizenship effect raises the employment rates for naturalised Chinese immigrants. In fact, naturalised Chinese immigrants often approach the Canadian-born employment rates over the lifecycle. However, the employment outcomes for naturalised citizens from the United Kingdom are mixed between the crucial ages of 25 to 45 as sometimes (aged 35-45) non-citizens have a greater employment rate than naturalised United Kingdom immigrants. 
Figure 4 Employment rates for naturalized citizens ( $C$ ) and non-citizens ( $\mathrm{NC}$ ) from Great Britain (Britlm) and China (Chinlm) by age group, 2001 Census of Canada $C B=$ Canadian born

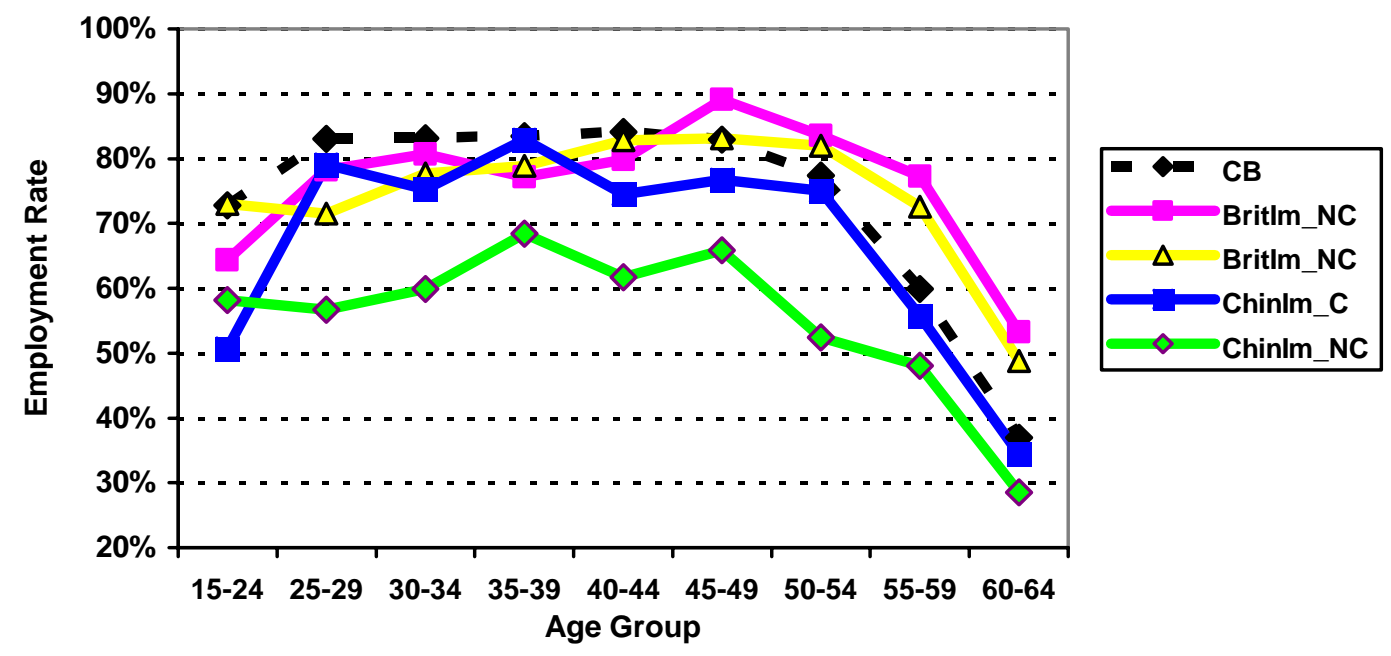

\section{Theory: Costs and Benefits of Ascending to Citizenship}

What would be the economic motivation for the immigrant citizenship candidate to acquire extra human capital and enjoy these positive economic gains when contemplating citizenship? First, the immigrant citizenship candidate has presumably observed greater occupational mobility and higher earnings for past-naturalised immigrants (Bratsberg et al. 2002). Given these observations of greater labour market opportunities after citizenship acquisition, the rational immigrant would accumulate more human capital to exploit this advantage if s/he had decided in advance (during the 3-5 year waiting period) to ascend to citizenship. In other words, naturalised citizens self select into citizenship based upon the potential economic benefits derived from acquiring citizenship. ${ }^{9}$ Thus, since naturalisation increases the return to human capital investment it may also cause those with greater capital accumulation to seek naturalisation and to increase incentives to those who are naturalised to acquire more human capital.

If this self-selection argument is correct, we should observe that moving into citizenship should be correlated with higher earnings and greater human capital acquisition for those who choose to naturalise as opposed to those who do not. 
Given these Canadian examples of the observed economic impacts derived from Canadian citizenship, I now turn to an economic-demographic model, which will predict differential rates of immigrant citizenship ascension and explain this observed rise in earnings.

The economic problem that immigrants face is to choose a state: citizenship or noncitizenship, which maximises their income net of citizenship ascension cost given their human capital stock.

Both the acquisition of subsidised human capital and the prospects of receiving a free public good (a passport) will increase the probability that this immigrant will ascend to citizenship, if the expected earnings stream in the host country - net of costs - exceeds the option of returning home.

In the absence of mutual recognition of dual citizenship by both Canada and the sending country, the major cost of ascending to Canadian citizenship is the loss of home country citizenship. This implies:

- no access to the home country labour market;

- the possible loss of the right to hold land, or the requirement to pay higher land taxes

- loss of entitlement to home country public services, such as subsidised education for children;

- curtailing of social benefits in origin country.

Application fees and any foregone income arising from continued residence in Canada to fulfil citizenship requirements add to the costs of ascending to citizenship.

On the other hand, the benefits from Canadian citizenship include:

- access to the federal government labour market;

- potential access to merged labour markets (e.g. NAFTA or EU);

- any wage premium paid by private employers to citizens;

- a host country passport with its implied visa waivers, which lead to greater worldwide mobility;

- immunity from a military conscription in home country:

- entitlement to participate in the political process 
All of these above features can be reduced to a set of hypotheses related to demographic, political and economic arguments which influence citizenship ascension. If this cost-benefit framework holds, then rates of ascension to citizenship will be related to the immigrant's age and years in the host country, and a positive function of skilled occupational status, since all these factors affect the economic returns to citizenship acquisition. Furthermore, home ownership, marital status and presence of children increase the costs of return migration and thus raise the incentive to naturalise. Finally, the greater the immigrant's earned income in the host country, the greater the probability of later ascending to citizenship. This income effect could also manifest itself in a greater desire of higher income people to obtain citizenship and participate in the political process.

In sum, human capital characteristics, and the host country institutional setting, plus immigrant source country characteristics (level of development, dual citizenship recognition, portability of home country passport) should be incorporated in a model of citizenship acquisition.

\section{Some Empirical Evidence on Immigrant Citizenship Ascension}

I will now introduce some explicit Canadian evidence to test the above hypotheses. The typical immigrant citizenship ascension model takes the form of logistic function $P\left(Y_{i}=1 \mid X_{i}\right)=\frac{\exp \left(X_{i} \beta\right)}{1+\exp \left(X_{i} \beta\right)}$ where $P\left(Y_{i}=1 \mid X_{i}\right)$ is the probability of observing a citizen in my immigrant sample conditioned on a vector of explanatory variables $X_{i}$ which includes individual attributes and the socio-economic context variables which, as we discussed earlier, may influence the naturalisation decision. The vector of parameters is estimated by the Maximum Likelihood Method. 
Table 1 Model of probability of acquiring Canadian citizenship: Immigrants from all countries

\begin{tabular}{ll|l|l|l|l}
\hline & Coeff. & b/St.Er. & P $[|\mathrm{Z}|>\mathrm{z}]$ & Mean of X & Elasticity \\
\hline Constant & 0.019187 & 0.164 & 0.8699 & & \\
AGEP & 0.007346 & 1.399 & 0.1617 & 45.88071 & 0.055009 \\
AGESQ & -0.00011 & -1.843 & 0.0654 & 2222.033 & -0.03937 \\
YSIM & 0.080457 & 74.192 & 0 & 24.54317 & 0.322278 \\
YIPOST75 & 0.01155 & 0.295 & 0.7682 & 0.347505 & 0.000654 \\
P75_YSIM & 0.021916 & 9.573 & 0 & 4.296566 & 0.015368 \\
TYS & -0.00023 & -7.85 & 0 & -57.6105 & 0.002147 \\
FEMALE & -0.10292 & -7.272 & 0 & 0.510275 & -0.00857 \\
PRO & 0.279808 & 14.964 & 0 & 0.220901 & 0.00957 \\
SKL & 0.1378 & 7.978 & 0 & 0.244092 & 0.005361 \\
LNTINC & 0.00012 & 4.106 & 0 & -42.07 & -0.00082 \\
HOWN & 0.192035 & 12.01 & 0 & 0.777668 & 0.02526 \\
DUAL & -0.19443 & -9.606 & 0 & 0.601698 & -0.01885 \\
CMA & 0.211616 & 11.696 & 0 & 0.834479 & 0.030215 \\
OECD & -1.25681 & -52.936 & 0 & 0.647082 & -0.11868 \\
\hline Number of observations & 154458 & Log likelihood function & -68474.07 \\
Chi squared & \multicolumn{2}{|l}{ Restricted log likelihood } & -76067.38 \\
\hline Non: Log & & 0 &
\end{tabular}

Notes: Logistic regression: dependent variable CTZN

Source: Calculations from pooled 2.8\% samples of 1991, 1996 and 2001 Censuses of Canada

In Table $1 \mathrm{I}$ report the results for the Canadian case of citizenship ascension for a sample drawn from Canada's major immigrant-sending countries. The maximum likelihood estimates of the logistic model yield a curvilinear relationship between age and the naturalisation rate. The fact that the rate of ascension is increasing in age but at decreasing rate is consistent with our human capital view of the naturalisation decision. In other words, the younger in age at naturalisation, the greater the lifetime benefits an immigrant can expect to accrue from her new citizenship status and hence the greater the log odds of naturalisation.

Years since immigration (YSIM) positively and significantly influenced the log odds of ascending to Canadian citizenship. As expected, the period dummy (YIPOST75: equal to 1 if immigrated after 1975, 0 - if otherwise) which reflects Canada's change in immigrant source regions from originally Europe (pre-1975) to non-European sources (post-1975) had a positive but statistically insignificant effect on naturalisation rates. ${ }^{10}$ Contrary to expectations the immigrant's total years of schooling (TYS) had a small and negatively 
signed effect on the immigrant's propensity to naturalise. ${ }^{11}$ The significantly negative coefficient for the gender dummy (FEMALE) suggests that males are more likely to ascend to Canadian citizenship, which supports Yang's (1994) findings.

The estimates in Table 1 also illustrate the role of economic assimilation in the naturalisation decision. Home ownership (HOWN) and the logarithm of total income (LNTINC) are significant conditioners and yield the predicted positive signs. Also, a higher occupational status (PRO - professional, SKL - skilled) yields a strong positive relationship with the rate of naturalisation.

Where the immigrant lived in Canada proves important since the Census metropolitan area indicator (CMA), is strong and positively signed. This outcome supports the idea that living in an urban environment fosters immigrant naturalisation. The significant negative coefficient for the OECD dummy indicates that the immigrant's source country level of development is an important determinant of citizenship ascension. Finally, dual citizenship (DUAL: equal to 1 if source country allows dual citizenship, 0 - if otherwise) does not have a positive effect on the probability of becoming a Canadian citizen.

In sum, demographic (age and gender), geographic (CMA), political (dual citizenship) and economic variables (home ownership, earned income, source country economic status) all significantly affected Canadian immigrant naturalisation circa 1991-2001.

Now that I have demonstrated that the ascension question can be analysed with economic, social and demographic variables in a utility maximising framework I now ask what is the economic impact derived from this Canadian immigrant naturalisation? Table 2 points to the economic impact on earnings derived from citizenship acquisition in the Canadian context circa 1991-2001. 
Table 2 OLS Estimation of log-linear earnings model: Citizenship Effect on immigrant earnings.

\begin{tabular}{|c|c|c|c|c|}
\hline & $\begin{array}{l}\text { (1) } \\
\text { females } \\
\text { non-OECD }\end{array}$ & $\begin{array}{l}(2) \\
\text { males } \\
\text { non-OECD }\end{array}$ & $\begin{array}{l}(3) \\
\text { females } \\
\text { OECD }\end{array}$ & $\begin{array}{l}(4) \\
\text { males } \\
\text { OECD }\end{array}$ \\
\hline Constant & $\begin{array}{l}4.632 \\
(42.820)\end{array}$ & $\begin{array}{l}4.357 \\
(40.563)\end{array}$ & $\begin{array}{l}4.411 \\
(49.593)\end{array}$ & $\begin{array}{l}4.457 \\
(54.064)\end{array}$ \\
\hline AGEP & $\begin{array}{l}.038 \\
(7.573)\end{array}$ & $\begin{array}{l}.055 \\
(11.286)\end{array}$ & $\begin{array}{l}.040 \\
(10.380)\end{array}$ & $\begin{array}{l}.071 \\
(20.581)\end{array}$ \\
\hline AGESQ & $\begin{array}{l}-.0004 \\
(-7.301)\end{array}$ & $\begin{array}{l}-.001 \\
(-10.904)\end{array}$ & $\begin{array}{l}.000 \\
(-9.762)\end{array}$ & $\begin{array}{l}-.001 \\
(-18.427)\end{array}$ \\
\hline YSIM & $\begin{array}{l}.013 \\
(16.293)\end{array}$ & $\begin{array}{l}.013 \\
(17.100)\end{array}$ & $\begin{array}{l}.003 \\
(6.642)\end{array}$ & $\begin{array}{l}.0005 \\
(-.605)\end{array}$ \\
\hline TYS & $\begin{array}{l}.035 \\
(18.015)\end{array}$ & $\begin{array}{l}.035 \\
(18.252)\end{array}$ & $\begin{array}{l}.037 \\
(21.404)\end{array}$ & $\begin{array}{l}.027 \\
(19.475)\end{array}$ \\
\hline LANG & $\begin{array}{l}.043 \\
(2.859)\end{array}$ & $\begin{array}{l}.097 \\
(6.349)\end{array}$ & $\begin{array}{l}.017 \\
(1.161)\end{array}$ & $\begin{array}{l}.081 \\
(6.578)\end{array}$ \\
\hline CITIZ & $\begin{array}{l}.126 \\
(7.713)\end{array}$ & $\begin{array}{l}.144 \\
(8.887)\end{array}$ & $\begin{array}{l}.058 \\
(5.128)\end{array}$ & $\begin{array}{l}.041 \\
(3.817)\end{array}$ \\
\hline PRO & $\begin{array}{l}.345 \\
(18.478)\end{array}$ & $\begin{array}{l}.289 \\
(16.534)\end{array}$ & $\begin{array}{l}.409 \\
(31.243)\end{array}$ & $\begin{array}{l}.356 \\
(29.978)\end{array}$ \\
\hline SKL & $\begin{array}{l}.089 \\
(5.361)\end{array}$ & $\begin{array}{l}.098 \\
(6.782)\end{array}$ & $\begin{array}{l}.174 \\
(15.321)\end{array}$ & $\begin{array}{l}.142 \\
(14.043)\end{array}$ \\
\hline LNWEEKS & $\begin{array}{l}.799 \\
(70.394)\end{array}$ & $\begin{array}{l}.812 \\
(63.307)\end{array}$ & $\begin{array}{l}.877 \\
(95.126)\end{array}$ & $\begin{array}{l}.759 \\
(70.164)\end{array}$ \\
\hline FTW & $\begin{array}{l}.594 \\
(34.890)\end{array}$ & $\begin{array}{l}.699 \\
(26.125)\end{array}$ & $\begin{array}{l}.700 \\
(63.248)\end{array}$ & $\begin{array}{l}.870 \\
(42.625)\end{array}$ \\
\hline $\begin{array}{l}\text { Adjusted R Square } \\
\text { F-statistics }\end{array}$ & $\begin{array}{l}.358 \\
1144.773\end{array}$ & $\begin{array}{l}.318 \\
1007.112\end{array}$ & $\begin{array}{l}.413 \\
2191.931\end{array}$ & $\begin{array}{l}.279 \\
1437.192\end{array}$ \\
\hline
\end{tabular}

*Note: t-statistics is given in brackets.

Authors calculations based on 1991, 1996 and 2001 Censuses PUMF

Holding constant other variables - age, schooling, years in Canada, language ability (LANG: equals 1 if English or French is spoken at home, equals 0 if otherwise) and labour market controls (LNWEEKS - natural logarithm of weeks worked, FTW - a dummy representing mainly full time weeks worked) - Canadian citizenship (CITIZ) increased immigrant annual wage earnings from 4 to 14.4 per cent. My results suggest that this citizenship earnings premium is greater for immigrants from less developed (i.e. non-OECD) countries. For example, females from non-OECD earn a 12.6 per cent premium versus a 5.8 per cent premium for OECD females. Males from the non-OECD group obtained a 14.4 per 
cent premium versus only a 4.1 per cent earnings boost in the OECD group after naturalisation.

In contrast to the citizenship effect, the earnings effect derived from the immigrant's occupational status is stronger for immigrants from developed countries in the OECD group. For example, the earnings advantage associated with skilled occupations for OECD females is almost twice as high as for non-OECD (17.4 per cent versus 8.9 per cent).

\section{Citizenship: The End of Discrimination?}

Economic gains from citizenship acquisition can arise from the immigrant acquiring human capital prior to citizenship or society conferring benefits on this human capital after citizenship or both. At this point we ask if the near equalised earnings for Canadian-born and naturalised citizens depicted in Figures 2 and 3 are a consequence of non-discriminatory treatment due to citizenship, or a result of the fact that newly ascended Canadian citizens have a greater stock of human capital or both? Given that immigrants are doubly selected, the average immigrant may have a greater human capital endowment than the average nativeborn Canadian. Then, after acquiring Canadian citizenship, do these better-educated and more experienced immigrants actually earn more than their native-born counterparts? If so, why? In order to answer these questions the literature employs the Blinder-Oaxaca decomposition methodology (Oaxaca 1973; Blinder 1974). The basic idea underlying this method is that differences in wages between two population groups can be explained by the differences in their productive characteristics, and by the differences in regression coefficients, which in turn represent returns to those characteristics.

The Oaxaca-Blinder decomposition has become a routine method in labour market discrimination studies to explain segmented group wage differences. In my case the citizenship status of an immigrant segments the labour market. Further, I must adopt one of the estimated wage structures as the non-discriminatory norm for the group believed to be dominant in the labour market (citizens) relative to the comparison group (non-citizens). I treat non-citizens as a disadvantaged group since non-citizens are discriminated against in the Canadian public sector given their limited job access. The results in Table 3 show that labour market outcomes for OECD and non-OECD naturalised immigrants when compared to the reference group of Canadian-born are drastically different. First, females from OECD 
countries reveal no wage differential since the positive effect owing to their better returns derived from their productive characteristics is offset by their smaller human capital endowments. In contrast, females from non-OECD countries show a 20.8 per cent wage disadvantage, which is evenly split between their smaller human capital endowments and the ‘discrimination’ component.

Even more dramatic differences follow from the decomposition analysis of the male sample. OECD-born males earn more as citizens because they possess greater human capital and earn greater returns to their human capital (i.e. a negative sign on 'discrimination' component). This results in a 12.8 per cent wage earnings advantage over native-born male citizens. In contrast, non-OECD males receive 26.5 per cent lower earnings of which 21.45 per cent is explained by smaller labour market rewards for their human capital characteristics.

Table 3 about here

In sum, I find that both male and female foreign-born Canadian citizens from non-OECD countries experienced discrimination in terms of lower rewards being paid for their acquired productive characteristics vis-à-vis the Canadian-born.

\section{Conclusions on the Common Ground}

What have we learned from this methodological review and one case study? First, in order to understand the causes and effects of citizenship acquisition we must treat the problem in a unified fashion. This is in contrast to the extant literature which emphasised that citizenship acquisition and impact are to be treated as two separate topics. With the recognition that citizenship ascension and its economic consequences are jointly determined a true common ground for economists and other social scientists now appears as a host of new variables absent in either the sociologist's or economist's analysis are introduced. For example, differential rates of citizenship ascension across immigrant groups are conditioned by political (dual citizenship) demographic (age) and social conditions (marital status) as well the rate of human capital accumulation in the host country in this merged model. In turn, citizenship status which is determined by the above conditions has an impact on immigrant 
employment and earnings and further conditions human capital accumulation. However, not all new citizens are rewarded equally from this investment.

Now I would argue that merging these two questions allows for the development of a multidisciplinary model embedded in the economist's cost-benefit calculus. In other words, each demographic, social or economic variable that enters either the ascension decision or impact effect will either raise the cost or return from an act of citizenship ascension for the representative immigrant. Thus, in different immigrant receiving countries with different costs and benefits to be derived from citizenship ascension the degree of naturalisation and the economic impacts arising from citizenship will differ. This comparative research agenda awaits the collaborative efforts of a team of social scientists to verify these predictions and to expand this methodological common ground. ${ }^{12}$

\section{Acknowledgements}

The Vancouver Centre of Excellence on Immigration and Integration (RIIM) provided support while writing this paper. The Willi Brandt Professorship, Malmö University, supported the background research on citizenship that is contained in this piece. The research assistance of Sergiy Pivnenko is noted with appreciation as well as Sydney Preston's copyediting. Critical remarks by C. Boswell clarified my arguments.

Notes

1 The author is Co-director of RIIM the Vancouver Centre that consists of approximately 75 researchers drawn from economics, education, geography and other social sciences. See www.riim.metropolis.net for a complete description of this multidisciplinary institute.

2 For example, International Migration Review and Journal of Immigration and Integration offer interdisciplinary articles.

3 At RIIM, economists as well as others have access to an administrative data base (IMDB) which contains records on over 4 million immigrants who arrived to Canada since 1981 including their yearly tax records. The existence of this data set alone has been a major inducement for economists to join RIIM.

4 The areas of immigrant health, education, intermarriage, language acquisition also lend themselves to possible collaborative analyses. See http://www.riim.metropolis.net/frameset_e.html for a sample of these attempts. 
5

Chiswick (1978) dissents from this finding when he argues that after controlling for a variety of factors citizenship acquisition did not improve the earnings prospects of United States immigrants.

6 weak rationale and ambiguous arguments on the direction of the effects of the cited variables to buttress his findings.

7 of endogeneity in this case. In particular, authors were trying to detect if citizenship premium and citizenship acquisition were determined simultaneously.

8 This and any further analysis utilizes the $2.8 \%$ sample of the Canadian Census Public Use Microdata Files (PUMFs).The immigrant population of interest is limited to individuals 25-65 years old, who have stayed in Canada at least 4 years and hence have become eligible for citizenship. The age-earnings profiles in Figures 2 and 3 are estimated at the mean values for the other relevant factors that affect their earnings. The determinants of immigrant earnings are listed in Table 2 later in this text.

9 Clearly, refugees are exempt from this economic argument since many refugees can not return and naturalization is often a foregone conclusion. Canadian Census data do not report the entry class of immigrants; hence I can not identify naturalization rates for Canadian refugees from this data source.

10 In 1976 a more liberal Immigration Act was adopted.

11 Higher education should yield higher rewards to citizenship, since the professionals will gain access to higher paid government jobs with citizenship.

12 RIIM researchers are currently conducting these citizenship studies for Norway, Sweden, Netherlands, Canada, Australia and the United States.

\section{References}

Bevelander, P. 2000. Immigrant employment integration and structural change in Sweden: 1970-1995. Lund Studies in Economic History 15. Lund: Lund University Press.

Bloemraad, I. 2000. Who claims dual citizenship? The limits of post nationalism, the possibilities of transnationalism, and the persistence of traditional citizenship. Department of Sociology, Harvard University. Unpublished manuscript.

—. 2000. Citizenship and immigration: A current review. Journal of Immigration and Integration 1 (1): 9-37.

Bratsberg B., J. F. Ragan and Z. M. Nasir. 2002. The effect of naturalization on wage growth: A panel study of young male immigrants. Journal of Labor Economics 20 (3): 568-97.

Chiswick, B. 1978. The effect of Americanization on the earnings of foreign-born men. Journal of Political Economy 86 (5): 897-921. 
DeVoretz, D. J. and J. Ma. 2002. Triangular human capital flows between sending, entrepôt and the rest-of-the-world regions. Canadian Studies in Population 29 (1): 53-69.

DeVoretz, D.J. and S. Pivnenko. 2004. Economics of Canadian citizenship. Willi Brandt Working Papers 3/04.

DeVoretz D.J. and S. Pivnenko. 2005 Self-Selection, Immigrant Public Finance Performance and Canadian Citizenship. RIIM Working Paper Series No., 05-07.

Mata, F. 1999. Patterns of acquiring citizenship. In Immigrant Canada: Demographic, Economic and Social Challenges, edited by S. S. Halli and L. Driedger, 163-82. Toronto: University of Toronto Press.

Pivnenko, S. and D. J. DeVoretz. 2004. The economic performance of Ukrainian immigrants in Canada and the United States. RIIM Working Paper Series No. 03-10. Also published as IZA Working Paper No. 913.

Scott, K. 1999. The immigrant experience: Changing employment and income patterns in Sweden, 1970-1993 . Lund Studies in Economic History 9. Lund: Lund University Press.

Yang, P.Q. 1994. Explaining immigrant naturalization. International Migration Review 28 (3): 449-77. 